\title{
A theoretical model for template-free synthesis of long DNA sequence
}

\author{
S. M. Minhaz Ud-Dean
}

Received: 31 December 2008/Revised: 17 March 2009/Accepted: 18 March 2009/Published online: 3 April 2009

(C) The Author(s) 2009. This article is published with open access at Springerlink.com

\begin{abstract}
This theoretical scheme is intended to formulate a potential method for high fidelity synthesis of Nucleic Acid molecules towards a few thousand bases using an enzyme system. Terminal Deoxyribonucleotidyl Transferase, which adds a nucleotide to the $3^{\prime} \mathrm{OH}$ end of a Nucleic Acid molecule, may be used in combination with a controlled method for nucleotide addition and degradation, to synthesize a predefined Nucleic Acid sequence. A pH control system is suggested to regulate the sequential activity switching of different enzymes in the synthetic scheme. Current practice of synthetic biology is cumbersome, expensive and often error prone owing to the dependence on the ligation of short oligonucleotides to fabricate functional genetic parts. The projected scheme is likely to render synthetic genomics appreciably convenient and economic by providing longer DNA molecules to start with.
\end{abstract}

Keywords Long DNA synthesis .

Enzyme system modelling - Synthetic gene ·

$\mathrm{pH}$ regulated synthesis .

Terminal deoxyribonucleotidyl transferase .

Genetic parts fabrication

\section{Abbreviations \\ 3'AcdN $\quad 3^{\prime}$ Acetyl deoxyribo nucleoside \\ $3^{\prime}$ AcdNA $\quad 3^{\prime}$ Acetyl deoxyribo nucleic acid}

S. M. Minhaz Ud-Dean ( $\square)$

Department of Genetic Engineering and Biotechnology,

University of Dhaka, Dhaka, Bangladesh

e-mail: minhazuddean@gmail.com

S. M. Minhaz Ud-Dean

Ashtabhuj Systems, 77 Basupara Main Road, Khulna,

Bangladesh $3^{\prime}$ AcdNDP $\quad 3^{\prime}$ Acetyl deoxyribo nucleoside di phosphate

$3^{\prime}$ AcdNMP $3^{\prime}$ Acetyl deoxyribo nucleoside mono phosphate

3'AcdNTP $\quad 3^{\prime}$ Acetyl deoxyribo nucleoside tri phosphate

Ac Acetyl group

$\mathrm{AcOH}$ Acetic acid (in equilibrium with acetate)

AE Acetylesterase, deacetylase (EC: 3.1.1.6)

AP Acid phosphatase (EC: 3.1.3.2)

DNA Deoxyribo nucleic acid

dNTP Deoxyribo nucleoside tri phosphate

ds Double strand

ID Inorganic diphosphatase (EC: 3.6.1.1)

$\mathrm{Kb} \quad$ Kilobase

$\mathrm{Mb} \quad$ Megabase

NA Nucleic acid

NTP Ribo nucleoside tri phosphate

P Phosphate group

PCR Polymerase chain reaction

RNA Ribo nucleic acid

ss $\quad$ Single strand

TdT Terminal deoxynucleotidyl transferase, DNA nucleotidyl exotransferase (EC: 2.7.7.31)

\section{Introduction}

To a great extent the progress in biotechnology and basic biomedical research has been centralized on the major advances in DNA synthesis and sequencing. Elucidation of the genetic code (Khorana 1968), production of synthetic gene (Agarwal et al. 1974), widespread use of PCR (Kleppe et al. 1971; Saiki et al. 1988), sequencing of the human genome (Venter et al. 2001; Lander et al. 2001), and the synthesis of whole genome of a microorganism (Gibson et al. 2008) are powerful examples. These 
applications along with many others have pivotally depended on the ability to synthesize short oligonucleotides, used as primers, typically ssDNA $10-80$ base in length (Caruthers 1985).

The widespread application of synthetic biology is essentially limited by the complexity and cost of assembling short oligonucleotides into longer functional DNA (Endy 2005). In addition to whole genomes (Hutchison et al. 1999; Smith et al. 2003; Gibson et al. 2008), construction of entire biochemical pathways (Martin et al. 2003; Mehl et al. 2003; Kodumal et al. 2004) and genetic circuitry (Elowitz and Leibler 2000; Sprinzak and Elowitz 2005) are illustrative of synthetic biology requiring synthesis of far more than a single gene. Therefore, the rapid availability of predefined DNA, more than $1 \mathrm{Mb}$ in length at a cost per base comparable to or less than oligonucleotides is greatly appealing. Despite important progress in this direction through building large numbers of genes by harnessing the massively parallel form of oligonucleotide synthesis to produce microarrays (Richmond et al. 2004; Tian et al. 2004), still the procedures depend on the chemical synthesis of short oligos. Thus the availability of longer DNA molecules is in principle restricted by the inherent limit of the chemical processes for oligonucleotide synthesis.

The error rate of synthesizing oligonucleotides is also of immense importance. At an error rate of 1 in $600 \mathrm{bp}$, it is required to sequence 10 clones to get a DNA construct of $1 \mathrm{~Kb}$ and 100 clones for $2 \mathrm{~Kb}$ (Baedeker and Schulz 1999; Withers-Martinez et al. 1999; Hoover and Lubkowski 2002; Chalmers and Curnow 2001). Thus large target fabrication is extremely difficult and error prone at this rate (Cello et al. 2002). The error was reduced to 1 in 1,400 bp by Tian et al. (2004) using microchip based multiplex synthesis. Protein mediated error correction has been utilized to reduce the rate further to 1 in 10,000 bp (Carr et al. 2004).

If the starting material is precise DNA molecules $1-10 \mathrm{~Kb}$ in length rather than $\sim 50$ bases, the speed and over all efficiency of synthetic genomics would tremendously increase because synthesis of longer constructs would be possible with fewer clones and sequencing. An extensive application of synthetic genes would be possible with a more convenient and reliable process for their fabrication. Thus an investigation for an efficient synthetic scheme is worth pursuing.

An attempt to delineate the necessary properties of a successful long DNA synthesis process leads to some salient features. Firstly, the error rate should be less than $10^{-4}$ in order to allow convenient synthesis of DNA constructs around $10^{5} \mathrm{bp}$ in length. Second, the maximum synthesizable length of DNA should be greater than $10^{5}$ as current protocols allow transformation with DNA constructs of up to $3 \times 10^{5}-20 \times 10^{5}$ bp in length (Glick and Pasternak
2003). These features indicate that preferably an enzymatic system might be successful. Moreover, enzymatic systems would in principle be more specific and efficient than chemical processes (Sitnitsky 2006). However, the enzymes those can synthesize DNA without templates are not controlled. For example TdT will add a homopolymeric tract of nucleotides when provided with a primer and a single type of NTP (Bollum 1978; Ratliff 1981). When provided with a mixture of nucleotides and a primer, TdT act as a random-sequence generator (Bollum 1978; Ratliff 1981). The physiological role of $\mathrm{TdT}$ conform to this random sequence generation as it provides additional variations in hematopoetic cells through acting as a somatic mutator, diversifying the amino acid sequence in the variable region of immunoglobulin molecules (Ratliff 1981).

TdT has already been utilized in genomics. It has been used for the production of synthetic homo and heteropolymers (Bollum 1974), homopolymeric tailing of linear duplex DNA (Deng and Wu 1983; Eschenfeldt et al. 1987), oligodeoxyribonucleotide and DNA labeling (Deng and $\mathrm{Wu}$ 1983; Tu and Cohen 1980; Vincent et al. 1982; Kumar et al. 1988; Igloi and Schiefermayr 1993), rapid amplification of cDNA ends (Frohman et al. 1988) and in situ localization of apoptosis (Gorczyca et al. 1993). Scheele and Fukuoka $(1992,1997)$ used TdT to add homopolymeric oligo dC tract to $3^{\prime}$ end of ss linear DNA in order to facilitate synthesis of ds linear DNA using oligo dG primer. However, no attempt to use TdT to synthesize a defined DNA sequence has been reported. Perhaps the random sequence generation by TdT in an uncontrolled system has prevented this.

Here a theoretical model for predefined long DNA synthesis based on TdT is proposed. The scheme depends on the addition of $3^{\prime}$ AcdNTP to the $3^{\prime}-\mathrm{OH}$ end of a DNA. The Ac group is suggested to prevent polymer formation and thus prevent the chain extension to a single base in each cycle (Fig. 1). After extension the $\mathrm{pH}$ of the system is decreased to activate $\mathrm{AE}$ and $\mathrm{AP}$ while TdT would be deactivated. AP would hydrolyze excess $3^{\prime}$ AcdNTP while AE would remove the Ac groups. Then dialysis would render the small molecules out of the system. Dialysis would also elevate the $\mathrm{pH}$ to activate TdT and deactivate $\mathrm{AE}$ and AP. Thus a new cycle of extension can be initiated by addition of $3^{\prime}$ AcdNTP. Theoretical analysis based on available data suggests the scheme to be highly promising in synthesizing long DNA molecules.

\section{Methods}

The scheme

Synthesis of a predefined DNA sequence requires the addition of a single known nucleotide at each step to a 
Fig. 1 Simplified scheme for TdT based DNA synthesis

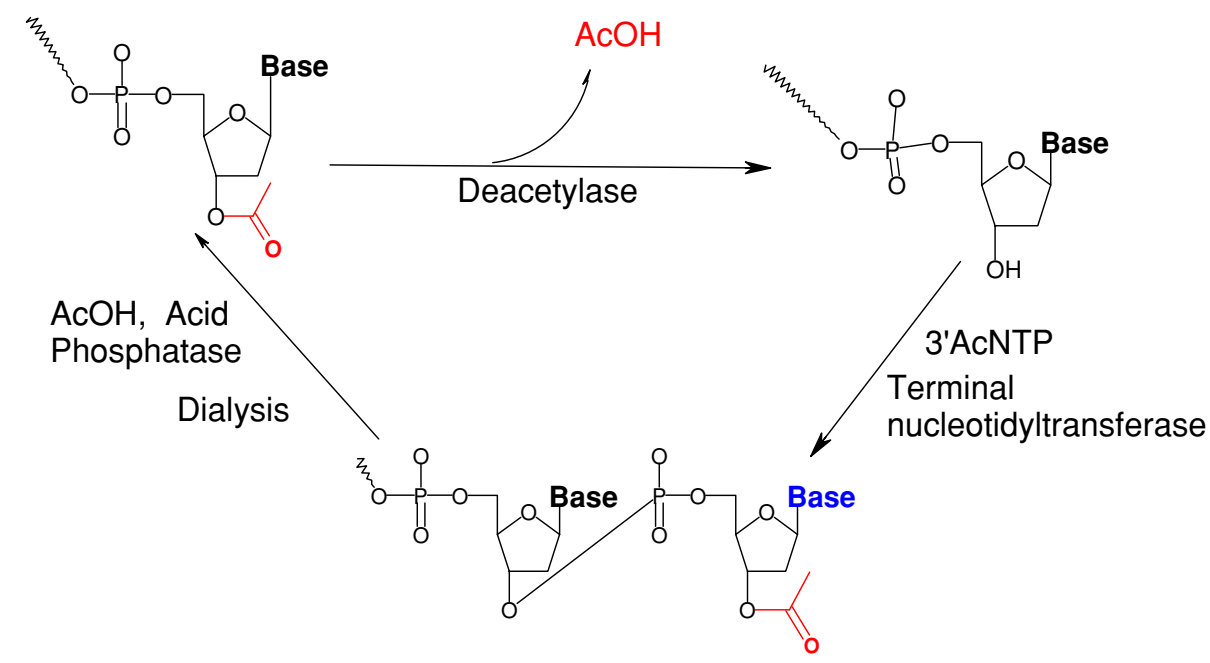

A new cycle of base addition must be preceded by removal of excess $3^{\prime}$ AcdNTP and deprotection of the $3^{\prime} \mathrm{OH}$ group of the extended DNA. Acid phosphatase (EC: 3.1.3.2) is a suitable candidate for hydrolysis of excess $3^{\prime}$ AcdNTP while acetylesterase is preferred for deprotection.

$\mathrm{DNA}_{n}+3^{\prime} \mathrm{AcdNTP} \stackrel{\mathrm{TdT}^{\prime}}{\longrightarrow} 3^{\prime} \mathrm{AcDNA}_{n+1}+\mathrm{PP}$

$\mathrm{PP} \stackrel{\mathrm{AP}}{\longrightarrow} 2 \mathrm{P}$

$3^{\prime} \mathrm{AcdNTP} \stackrel{\mathrm{AP}}{\longrightarrow} \mathrm{P}+3^{\prime} \mathrm{AcdNDP} \stackrel{\mathrm{AP}}{\longrightarrow} 2 \mathrm{P}+3^{\prime} \mathrm{AcdNMP}$

$3^{\prime} \mathrm{AcDNA}_{n+1} \stackrel{\mathrm{AE}}{\longrightarrow} \mathrm{AcOH}+\mathrm{DNA}_{n+1}$

However the process raises problem regarding precise temporal order. As depicted in Fig. 2, if the protective Ac group is removed before complete hydrolysis of $3^{\prime}$ AcdNTP, additional bases may add to the extended DNA. Moreover AE deacetylates wide range substrates. Thus 3'AcdNTP may become deacetylated before incorporation into DNA. This event would also fail the objective. Thus TdT must be inactive when AE is active and vice versa. Bovine TdT has a $\mathrm{pH}$ optimum at 7.5 and has limited activity below pH 6.9 (Coleman 1977) however it is stable at $\mathrm{pH}$ down to 4.5. On the other hand Aspergillus niger $\mathrm{AE}$ has a $\mathrm{pH}$ optimum of 5.5 with limited activity over pH 6 (Kormelink et al. 1993). A. niger AE is however stable at $\mathrm{pH} 8$. Therefore, the elongation step should be catalyzed by $\mathrm{TdT}$ at $\mathrm{pH} 7.5$ while the deprotection step should take place at $\mathrm{pH}$ 5.5.

Penicillium chryrsogenum acid phosphatase has $\mathrm{pH}$ optimum at pH 5.5 (Haas et al. 1991). Therefore it is expected to be an efficient scavenger of excess $3^{\prime}$ AcdNTP after elongation. E. coli inorganic diphosphatase (EC: 3.6.1.1) has $\mathrm{pH}$ optimum at $\mathrm{pH} 7.5$ (Vainonen et al. 2005). Thus it can be utilized to hydrolyze pyrophosphate formed during elongation by TdT. 
Fig. 2 Lack of precise temporal order in removal of excess modified NTP and deacetylation may lead to unintended chain elongation

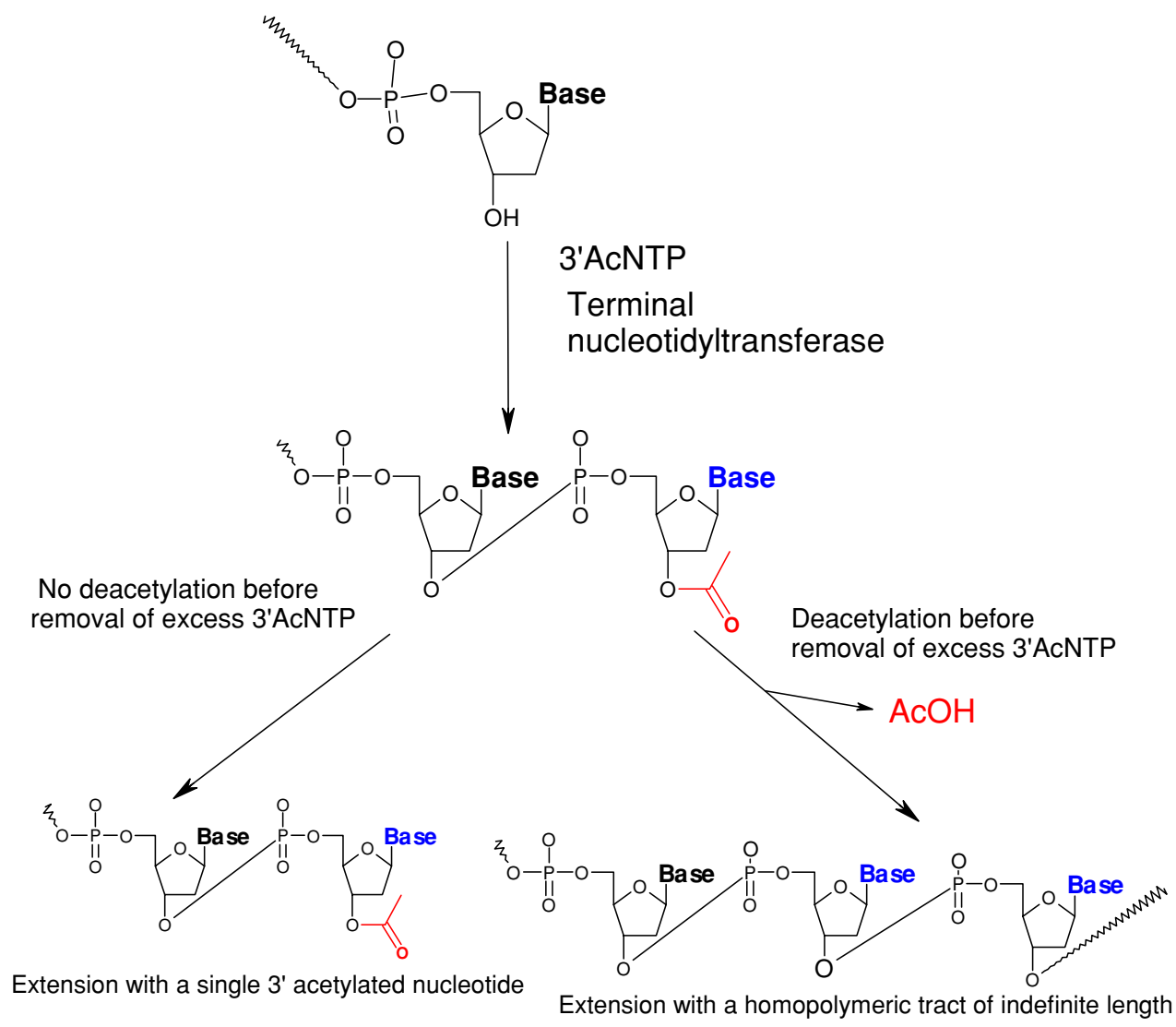

$\mathrm{DNA}_{n}+3^{\prime} \mathrm{AcdNTP}^{\mathrm{TdT}, \mathrm{pH}} \stackrel{\text { 7.5 }}{\longrightarrow} 3^{\prime} \mathrm{AcDNA}_{n+1}+\mathrm{PP}$

$\mathrm{PP} \stackrel{\mathrm{ID}, \mathrm{pH}^{7.5}}{\longrightarrow} 2 \mathrm{P}$

$3^{\prime} \operatorname{AcdNTP} \stackrel{\mathrm{AP}, \mathrm{pH} 5.5}{\longrightarrow} \mathrm{P}+3^{\prime}$ AcdNDP $\stackrel{\mathrm{AP}, \mathrm{pH} 5.5}{\longrightarrow}$

$2 \mathrm{P}+3^{\prime}$ AcdNMP

$3^{\prime} \mathrm{AcDNA}_{n+1} \stackrel{\mathrm{AE}, \mathrm{pH}}{\longrightarrow}{ }^{5.5} \mathrm{AcOH}+\mathrm{DNA}_{n+1}$

The rapid change is $\mathrm{pH}$ demanded by such a $\mathrm{pH}$ controlled system would be very difficult to achieve in a traditional reactor system. A nanoreactor would provide distinctive advantage of rapid condition alteration. Thus, the enzyme system in a nanoreactor coupled with $\mathrm{pH}$ regulation is a promising one for template free long DNA synthesis.

Thermodynamics of the scheme

The free energy of the intended reactions would depend on the concentration of the reactants and products. The choice of reactant concentration is determined by the intended concentration of the product. DNA concentration of $10^{-12} \mathrm{M}$ is enough for most molecular biology protocols (Sambrook and Russel 2001). In order to synthesize sufficient amount of DNA for molecular biology protocols, here we arbitrarily set the intended product concentration to be $10^{-9} \mathrm{M}$. For the sake of the completeness of the reaction the initial concentrations in Table 1 are proposed.

In the reaction:

$\mathrm{DNA}_{n}+3^{\prime} \mathrm{AcdNTP}^{\mathrm{TdT}, \mathrm{pH}} \stackrel{\text { 7.5 }}{\longrightarrow} 3^{\prime} \mathrm{AcdNA}_{n+1}+\mathrm{PP}$

A phosphodiester bond is synthesized while an ester bond between $\alpha$ and $\beta$ phosphate of the $3^{\prime}$ AcdNTP is hydrolyzed. The $\Delta G^{\mathrm{o} /}$ of synthesizing a phosphodiester
Table 1 Proposed initial concentration of reactants in the synthetic scheme

\begin{tabular}{ll}
\hline Species & $\begin{array}{l}\text { Initial } \\
\text { concentration } \\
(\mathrm{M})\end{array}$ \\
\hline $\begin{array}{l}\text { Primer } \\
\left(\text { DNA }_{n}\right)\end{array}$ & $10^{-9}$ \\
3'AcdNTP $^{\prime}$ & $10^{-8}$ \\
TdT & $10^{-8}$ \\
PP & $<10^{-12}$ \\
P & $<10^{-12}$ \\
$3^{\prime}$ AcDNA & $<10^{-15}$ \\
DNA $_{n+1}$ & $<10^{-15}$ \\
AcOH & $10^{-8}$ \\
$\mathrm{H}_{2} \mathrm{O}$ & 55.5 \\
$3^{\prime}$ AcdNMP & $10^{-8}$ \\
TdT & $10^{-8}$ \\
\hline
\end{tabular}


bond is $+22.2 \mathrm{KJ} \mathrm{mol}^{-1}$ (Dickson et al. 2000) while $\Delta G^{\mathrm{o} /}$ of hydrolyzing bond between $\alpha$ and $\beta$ phosphate of nucleotides is $-32.2 \mathrm{KJ} \mathrm{mol}^{-1}$ (Voet and Voet 2004). Thus the $\Delta G^{\mathrm{o} /}$ of the above reaction would be very close to $-10 \mathrm{KJ} \mathrm{mol}^{-1}$. For the concentrations of reactants in table (1) the value of $\Delta G$ is $-69.3 \mathrm{KJ} \mathrm{mol}^{-1}$.

In the next reaction:

$\mathrm{PP}^{\mathrm{ID}, \mathrm{pH}^{7.5}} \stackrel{\mathrm{P}}{\longrightarrow}$

An ester bond between two phosphate groups of a pyrophosphate is hydrolyzed. $\Delta G^{\mathrm{o} /}$ of this reaction is $-33.5 \mathrm{KJ} \mathrm{mol}^{-1}$ (Voet and Voet 2004). For the concentrations of reactants in table (1) the value of $\Delta G$ is $-115.1 \mathrm{KJ} \mathrm{mol}^{-1}$.

The following reaction:

$$
\begin{aligned}
& 3^{\prime} \text { AcdNTP } \stackrel{\mathrm{AP}, \mathrm{pH} 5.5}{\longrightarrow} \mathrm{P}+3^{\prime} \text { AcdNDP } \stackrel{\mathrm{AP}, \mathrm{pH} 5.5}{\longrightarrow} 2 \mathrm{P} \\
& \quad+3^{\prime} \text { AcdNMP }
\end{aligned}
$$

Two high energy phosphate bonds are hydrolyzed. The $\Delta G^{\mathrm{o} /}$ of this reaction is $-65.7 \mathrm{KJ} \mathrm{mol}^{-1}$ (Voet and Voet 2004). For the concentrations of reactants in table (1) the value of $\Delta G$ is $-181.4 \mathrm{KJ} \mathrm{mol}^{-1}$.

The following reaction:

$3^{\prime} \mathrm{AcDNA}_{n+1} \stackrel{\mathrm{AE}, \mathrm{pH} 5.5}{\longrightarrow} \mathrm{AcOH}+\mathrm{DNA}_{n+1}$

breaks an ester bond and a $\mathrm{H}-\mathrm{OH}$ bond while creates a $\mathrm{CH}_{3} \mathrm{C}(\mathrm{O})-\mathrm{OH}$ and a $\mathrm{RO}-\mathrm{H}$ bond. The bond dissociation energies of ester, $\mathrm{H}-\mathrm{OH}, \mathrm{CH}_{3} \mathrm{C}(\mathrm{O})-\mathrm{OH}$ and $\mathrm{RO}-\mathrm{H}$ bonds are $433.1,497.4,456.2$ and $425.1 \mathrm{KJ} \mathrm{mol}^{-1}$ respectively (Luo 2007). Thus $\Delta H^{\mathrm{o}}$ of this reaction would be close to $+49.2 \mathrm{KJ} \mathrm{mol}^{-1}$. Both the products of the reaction are soluble in water, thus the entropy of the reaction would be positive in aqueous media. Therefore, $\Delta G^{\mathrm{o}}$ of this reaction would be less than $\Delta H^{\mathrm{o}}$. For the concentrations of reactants in table (1) the value of $\Delta G$ should be less than $-44.2 \mathrm{KJ} \mathrm{mol}^{-1}$. Moreover, the activation energy of hydrolysis of acetate ester in water is around $+40 \mathrm{KJ} \mathrm{mol}^{-1}$ at temperature $35-37^{\circ} \mathrm{C}$ (Aksnes and Libanu 1991). Therefore, the reactants would be kinetically stable in absence of an active catalyst.

\section{Results}

The study on enzyme properties and possible combinations suggests that an enzymatic synthesis of predefined long DNA molecule is theoretically plausible. Based on the available data the process depicted in Fig. 3 is expected to be successful. AcOH would be added to decrease the $\mathrm{pH}$ to 5.5 while dialysis in a buffer of $\mathrm{pH} 7.5$ would serve multiple functions, including removal of $\mathrm{AcOH}$, phosphate groups, nucleosides and other small molecules in addition to restoring the $\mathrm{pH}$ to 7.5 .

Incubation time $\mathrm{T} 1$ would depend on the relative concentration of TdT, primer, $3^{\prime}$ AcdNTP and ID. The total time required for completing a step of the synthetic scheme would be determined according to the following equation:

$$
\begin{aligned}
t_{\text {step }}= & \text { time required for } \mathrm{pH} \text { switching }+ \\
& \text { time required for reaction completion } \\
t_{\text {step }}= & \frac{0.6 a^{2}}{D}+\frac{1}{K_{\text {cat }}[E]_{0}}\left(K_{\mathrm{M}} \ln \frac{[\mathrm{S}]_{1}}{[\mathrm{~S}]_{2}}+\left([\mathrm{S}]_{1}-[\mathrm{S}]_{2}\right)\right)
\end{aligned}
$$

where, $a$ is radius of the reactor, $K_{\text {cat }}$ is turnover number of the enzyme, $D$ is diffusion coefficient of $\mathrm{H}^{+}$ions, $[\mathrm{S}]_{1}$ is initial substrate concentration, $[\mathrm{S}]_{2}$ is intended final substrate concentration, $[E]_{0}$ is initial concentration of enzyme, $K_{\mathrm{M}}$ is Michaelis constant of the enzyme for the substrate.

In order to complete $\mathrm{pH}$ switching within less than $0.1 \mathrm{~s}$ the radius of the reactor should be less than $3.94 \times 10^{-3} \mathrm{~cm}$ with a volume less than $1.92 \times 10^{-7} \mathrm{ml}$ or $0.19 \mathrm{nl}$. As an enzyme catalyzed reaction is designed to take place in nano liter volume, the reactor is named nanobioreactor. Use of nanobioreactors would greatly reduce the time of $\mathrm{pH}$ switching and thus lead to faster synthesis.

Incubation time $\mathrm{T} 2$ would depend on the size of the reactor, $K_{\text {cat }}[\mathrm{AP}]$ and $K_{\text {cat }}[\mathrm{AE}]$. The smaller the reactor the less time would be necessary to activate $\mathrm{AE}$ and $\mathrm{AP}$ through shift in $\mathrm{pH}$. Moreover, a slow $\mathrm{pH}$ shift may lead to a transitory period with both TdT, ID and AP, AE enzyme pairs active; thus increase error rate. Therefore a rapid $\mathrm{pH}$ change essential. Higher enzyme activity would decrease the time required for complete hydrolysis of excess bases and deprotection of $3^{\prime}-\mathrm{OH}$ groups. Incubation time T3
Fig. 3 Proposed protocol for DNA synthesis utilizing the scheme

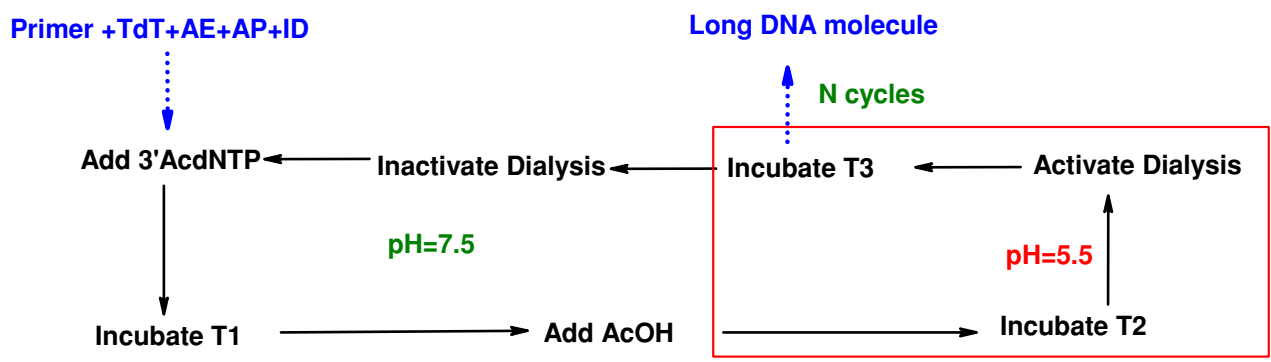


would depend mostly on the time required to restore the $\mathrm{pH}$ back to 7.5. Thus the size of the reactor would again be an important factor.

Number of possible cycles $\mathrm{N}$ would depend on the error rate, which would in turn depend on the completeness of reaction at each step. As reaction of each step in the cycle is thermodynamically favorable, the completeness is in principle warranted, provided with sufficient time. Since the $K_{\mathrm{M}}$ of TdT for oligonucleotide primer is in the range of $10^{-4}$, at equivalent molar ratio with primer $\mathrm{Td} \mathrm{T}$ is expected to make less than 1 in 10,000 errors. The error rate may however increase if incubation time $\mathrm{T} 1$ is longer due to slow $\mathrm{pH}$ shift. Thus faster $\mathrm{pH}$ shift would maintain high fidelity.

\section{Discussion}

The scheme proposed here is a potentially efficient enzymatic method for de novo DNA synthesis. From available data on the thermodynamics of the reactions and properties of the involved enzymes, the scheme is theoretically feasible. However, experimental demonstration would be crucial for its practical application.

A major difficulty may be the low turnover number of TdT with $3^{\prime}$ AcdNTP as substrate. From the reported results of incorporation of modified bases by TdT (Deng and Wu 1983; Tu and Cohen 1980; Vincent et al. 1982; Kumar et al. 1988; Igloi and Schiefermayr 1993), it is inferred that TdT would accommodate an acetyl group. Recombinant enzymes are likely to be available to circumvent the problem in case native TdT does not incorporate $3^{\prime} \mathrm{Ac}$ dNTP. Recombinant enzymes may also lead to a TdT with higher affinity to primers further limiting the error rate.

Nanobioreactors with capabilities of rapid change in $\mathrm{pH}$ would offer great advantage not only for this scheme but also for synthetic methods requiring sequential temporal activity switching of different sets of enzymes. Enzymatic correction (Carr et al. 2004) may be used on the longer DNA sequences. This combination may limit the error further down to 1 in 150,000 . The availability of longer DNA for gene assembly would significantly increase the power and range of synthetic genomics. Not only small microorganism genomes, large genomes of higher organisms may also become amenable to synthesis with longer starting material.

Acknowledgement This study was carried out with support from Ashtabhuj Systems.

Conflict of interest The author declares that he has no conflict of interest.

Open Access This article is distributed under the terms of the Creative Commons Attribution Noncommercial License which permits any noncommercial use, distribution, and reproduction in any medium, provided the original author(s) and source are credited.

\section{References}

Agarwal KL, Buchi H, Caruthers MH, Gupta N, Khorana HG, Kleppe K, Kumar A, Ohtsuka E, Rajbhandary UL, Van de Sande JH et al (1974) Total synthesis of the gene for an alanine transfer ribonucleic acid from yeast. Nature 227:27-34. doi:10.1038/227027a0

Aksnes G, Libanu FO (1991) Temperature dependence of ester hydrolysis in water. Acta Chem Scand 45:463-468. doi:10.3891/ acta.chem.scand.45-0463

Baedeker M, Schulz GE (1999) Overexpression of a designed $2.2 \mathrm{~kb}$ gene of eukaryotic phenylalanine ammonia-lyase in Escherichia coli. FEBS Lett 457:57-60. doi:10.1016/S0014-5793(99)01000-5

Barthelmes J, Ebeling C, Chang A, Schomburg I, Schomburg D (2007) BRENDA, AMENDA and FRENDA: the enzyme information system in 2007. Nucleic Acids Res. doi:10.1093/ nar/gk1972

Bollum FJ (1974) Terminal deoxynucleotidyl transferase. In: Boyer PD (ed) The enzymes, vol 10, 3rd edn. Academic Press, New York, pp 145-171

Bollum FJ (1978) Terminal deoxynucleotidyl transferase: biological studies. Adv Enzymol Relat Areas Mol Biol 47:347-374

Carr PA, Park JS, Lee YJ, Yu T, Zhang S, Jacobson JM (2004) Protein-mediated error correction for de novo DNA synthesis. Nucleic Acids Res. doi:10.1093/nar/gnh160

Caruthers MH (1985) Gene synthesis machines: DNA chemistry and its uses. Science 230:281-285. doi:10.1126/science.3863253

Cello J, Paul AV, Wimmer E (2002) Chemical synthesis of poliovirus cDNA: generation of infectious virus in the absence of natural template. Science 297:1016-1018. doi:10.1126/science.1072266

Chalmers FM, Curnow KM (2001) Scaling up the ligase chain reaction-based approach to gene synthesis. Biotechniques 30: 249-252

Coleman MS (1977) Terminal deoxynucleotidyl transferase: characterization of extraction and assay conditions from human and calf tissue. Arch Biochem Biophys 182:525-532. doi:10.1016/ 0003-9861(77)90533-1

Deng GR, Wu R (1983) Terminal transferase: use in the tailing of DNA and for in vitro mutagenesis. Methods Enzymol 100:96116. doi:10.1016/0076-6879(83)00047-6

Dickson KS, Burns CM, Richardson JP (2000) Determination of the free-energy change for repair of a DNA phosphodiester bond. J Biol Chem 275:15828-15831. doi:10.1074/jbc.M910044199

Elowitz MB, Leibler S (2000) A synthetic oscillatory network of transcriptional regulators. Nature 403:335-338. doi:10.1038/ 35002125

Endy D (2005) Foundations for engineering biology. Nature doi:10.1038/nature04342

Eschenfeldt WH et al (1987) Homopolymeric tailing. Methods Enzymol 152:337-342. doi:10.1016/0076-6879(87)52040-7

Frohman MA et al (1988) Rapid production of full-length cDNAs from rare transcripts: amplification using a single gene-specific oligonucleotide primer. Proc Natl Acad Sci USA 85:8998-9002. doi:10.1073/pnas.85.23.8998

Gibson DG, Benders GA, Andrews-Pfannkoch C, Denisova EA, Baden-Tillson H, Zaveri J, Stockwell TB, Brownley A, Thomas DW, Algire MA, et al (2008) Complete chemical synthesis, assembly and cloning of a Mycoplasma genitalium genome. Science doi:10.1126/science.1151721

Glick BR, Pasternak JJ (2003) Molecular biotechnology: principles and applications of recombinant DNA, 3rd edn. ASM Press, Washington DC, $\mathrm{p} 81$

Gorczyca W et al (1993) Detection of DNA strand breaks in individual apoptotic cells by the in situ terminal deoxynucleotidyl transferase and nick translation assays. Cancer Res 53:1945-1951 
Haas H, Redl B, Leitner E, Stöffler G (1991) Penicillium chrysogenum extracellular acid phosphatase: purification and biochemical characterization. Biochim Biophys Acta 1074:392-397

Hoover DM, Lubkowski J (2002) DNA works: an automated method for designing oligonucleotides for PCR-based gene synthesis. Nucleic Acids Res 30:e43. doi:10.1093/nar/30.10.e43

Hutchison CA, Peterson SN, Gill SR, Cline RT, White O, Fraser CM, Smith HO, Venter JC (1999) Global transposon mutagenesis and a minimal Mycoplasma genome. Science 286:2165-2169. doi:10.1126/science.286.5447.2165

Igloi GL, Schiefermayr E (1993) Enzymatic addition of fluoresceinor biotin-riboUTP to oligonucleotides results in primers suitable for DNA sequencing and PCR. Biotechniques 15:486-497

Khorana HG (1968) Nucleic acid synthesis in the study of the genetic code. In: Nobel lectures: physiology or medicine (1963-1970). Elsevier Science Ltd, Amsterdam, pp 341-369

Kleppe K, Ohtsuka E, Kleppe R, Molineux I, Khorana HG (1971) Studies on polynucleotides XCVI. Repair replications of short synthetic DNA's as catalyzed by DNA polymerases. J Mol Biol 56:341-361. doi:10.1016/0022-2836(71)90469-4

Kodumal SJ, Patel KG, Reid R, Menzella HG, Welch M, Santi DV (2004) Total synthesis of long DNA sequences: synthesis of a contiguous $32-\mathrm{kb}$ polyketide synthase gene cluster. Proc Natl Acad Sci USA 101:15573-15578. doi:10.1073/pnas.0406911101

Kormelink FJM, Lefebvre B, Strozyk F, Voragen AGJ (1993) Purification and characterization of an acetyl xylan esterase from Aspergillus niger. J Biotechnol 27:267-282. doi:10.1016/01681656(93)90090-A

Kumar A et al (1988) Nonradioactive labeling of synthetic oligonucleotide probes with terminal deoxynucleotidyl transferase. Anal Biochem 169:376-382. doi:10.1016/0003-2697(88)90299-0

Lander ES, Linton LM, Birren B, Nusbaum C, Zody MC, Baldwin J, Devon K, Dewar K, Doyle M, FitzHugh W et al (2001) Initial sequencing and analysis of the human genome. Nature 409:860 921. doi: $10.1038 / 35057062$

Luo Y-R (2007) Comprehensive handbook of chemical bond energies. CRC Press, Boca Raton, pp 255-338

Martin VJ, Pitera DJ, Withers ST, Newman JD, Keasling JD (2003) Engineering a mevalonate pathway in Escherichia coli for production of terpenoids. Nat Biotechnol 21:796-802. doi:10.1038/ nbt833

Mehl RA, Anderson JC, Santoro SW, Wang L, Martin AB, King DS, Horn DM, Schultz PG (2003) Generation of a bacterium with a 21 amino acid genetic code. J Am Chem Soc 125:935-939. doi:10.1021/ja0284153

Ratliff RL (1981) Terminal deoxyribonucleotidyl transferase. In: Boyer PD (ed) The enzymes, vol 14, 3rd edn. Academic Press, New York, pp 105-118

Richmond KE, Li MH, Rodesch MJ, Patel M, Lowe AM, Kim C, Chu LL, Venkataramaian N, Flickinger SF, Kaysen J et al (2004) Amplification and assembly of chip-eluted DNA (AACED): a method for high-throughput gene synthesis. Nucleic Acids Res 32:5011-5018. doi:10.1093/nar/gkh793
Saiki RK, Gelfand DH, Stoffel S, Scharf SJ, Higuchi R, Horn GT, Mullis KB, Erlich HA (1988) Primer-directed enzymatic amplification of DNA with a thermostable DNA polymerase. Science 239:487-491. doi:10.1126/science.2448875

Sambrook J, Russel D (2001) Molecular cloning: a laboratory manual, vol 2, 3rd edn. Cold Harbor Laboratory Press, Cold Spring Harbor, pp 8.18-8.25

Scheele G, Fukuoka S-I (1992) Synthesis of full-length doublestranded DNA from a single-stranded linear DNA template. US Patent 5162209

Scheele G, Fukuoka S-I (1997) Synthesis of full-length doublestranded DNA from a single-stranded linear DNA template. US Patent 5643766

Schomburg I, Chang A, Schomburg D (2002) BRENDA, enzyme data and metabolic information. Nucleic Acids Res 30:47-49. doi:10.1093/nar/30.1.47

Schomburg I, Chang A, Ebeling C, Gremse M, Heldt C, Huhn G, Schomburg D (2004) BRENDA, the enzyme database: updates and major new developments. Nucleic Acids Res 32:D431D433. doi:10.1093/nar/gkh081

Sitnitsky AE (2006) Dynamical contribution into enzyme catalytic efficiency. Physica A doi:10.1016/j.physa.2006.03.039

Smith HO, Hutchison CA, Pfannkoch C, Venter JC (2003) Generating a synthetic genome by whole genome assembly: $\Phi$ X174 bacteriophage from synthetic oligonucleotides. Proc Natl Acad Sci USA 100:15440-15445. doi:10.1073/pnas.2237126100

Sprinzak D, Elowitz MB (2005) Reconstruction of genetic circuits. Nature. doi:10.1038/nature04335

Tian J, Gong H, Sheng N, Zhou X, Gulari E, Gao X, Church GM (2004) Accurate multiplex gene syntheses from programmable DNA chips. Nature 432:1050-1053. doi:10.1038/nature03151

Tu C-PD, Cohen SN (1980) 3'-end labeling of DNA with [alfa- ${ }^{32} \mathrm{P}$ ] cordycepin-5'-triphosphate. Gene 10:177-183. doi: 10.1016/0378-1119(80)90135-3

Vainonen JP, Vorobyeva NN, Rodina EV, Nazarova TI, Kurilova SA, Skoblov JS, Avaeva SM (2005) Metal-free PPi activates hydrolysis of MgPPi by an Escherichia coli inorganic pyrophosphatase. Biochemistry (Mosc) 70:69-78

Venter JC, Adams MD, Myers EW, Li PW, Mural RJ, Sutton GG, Smith HO, Yandell M, Evans CA, Holt RA et al (2001) The sequence of the human genome. Science 291:1304-1351. doi:10.1126/science. 1058040

Vincent $C$ et al (1982) Synthesis of 8-(2, 4-dinitrophenyl-2, 6-aminohexyl)aminoadenosine-5'-triphosphate: biological properties and potential uses. Nucleic Acids Res 10:6787-6796. doi:10.1093/nar/10.21.6787

Voet D, Voet JG (2004) Biochemistry, 3rd edn. Wiley, New York, p 566

Withers-Martinez C, Carpenter EP, Hackett F, Ely B, Sajid M, Grainger M, Blackman MJ (1999) PCR-based gene synthesis as an efficient approach for expression of the $\mathrm{A}+\mathrm{T}$-rich malaria genome. Protein Eng 12:1113-1120. doi:10.1093/protein/12. 12.1113 